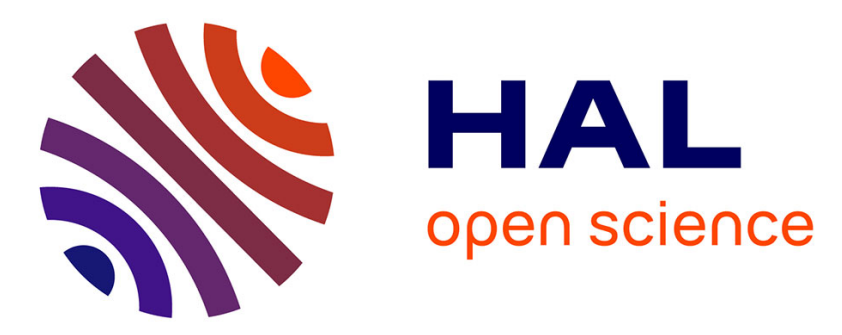

\title{
First Jurassic occurence of Enoploclytia M'Coy, 1849 (Crustacea: Decapoda: Erymidae)
} Julien Devillez, Sylvain Charbonnier, Jean-Philippe Pezy

\section{To cite this version:}

Julien Devillez, Sylvain Charbonnier, Jean-Philippe Pezy. First Jurassic occurence of Enoploclytia M'Coy, 1849 (Crustacea: Decapoda: Erymidae). Annales de Paléontologie, 2018, 104 (2), pp.143-148. 10.1016/j.annpal.2018.01.003 . hal-01730602

\section{HAL Id: hal-01730602 https://hal.sorbonne-universite.fr/hal-01730602}

Submitted on 13 Mar 2018

HAL is a multi-disciplinary open access archive for the deposit and dissemination of scientific research documents, whether they are published or not. The documents may come from teaching and research institutions in France or abroad, or from public or private research centers.
L'archive ouverte pluridisciplinaire HAL, est destinée au dépôt et à la diffusion de documents scientifiques de niveau recherche, publiés ou non, émanant des établissements d'enseignement et de recherche français ou étrangers, des laboratoires publics ou privés. 


\title{
Première occurrence d'Enoploclytia M'Coy, 1849 (Crustacea : Decapoda : Erymidae) dans le Jurassique
}

\section{First occurence of Enoploclytia M'Coy, 1849 (Crustacea: Decapoda: Erymidae) in the Jurassic}

\author{
Julien Devillez \\ Muséum national d'Histoire naturelle, Paris \\ Centre de Recherche sur la Paléobiodiversité et les Paléoenvironnements (CR2P, UMR 7207), Sorbonne \\ Universités, MNHN, UPMC, CNRS, 57 rue Cuvier F-75005 Paris (France) \\ julien.devillez@edu.mnhn.fr
}

Sylvain Charbonnier

Muséum national d'Histoire naturelle, Paris

Centre de Recherche sur la Paléobiodiversité et les Paléoenvironnements (CR2P, UMR 7207), Sorbonne

Universités, MNHN, UPMC, CNRS, 57 rue Cuvier F-75005 Paris (France)

sylvain.charbonnier@mnhn.fr

Jean-Philippe Pezy

Normandie Univ, UNICAEN, CNRS, M2C, 14000 CAEN, France

jean-philippe.pezy@unicaen.fr

RÉSUMÉ

Parmi les Erymidae Van Straelen, 1925, connus dès le Permien supérieur (Changhsingien) et répandus au Jurassique, le genre Enoploclytia M'Coy, 1849 passe pour être apparu tardivement en raison de son absence avant le Crétacé. Jusqu'à présent, le plus ancien représentant était E. augustobonae Devillez, Charbonnier, Hyžný \& Leroy, 2016 du Crétacé inférieur (Barrémien) de l'est du bassin de Paris (France). Cependant, un nouveau fossile récolté en Normandie (France), présentant une architecture des sillons de la carapace typique d'Enoploclytia, atteste de la présence du genre dès le Jurassique supérieur (Oxfordien).

\section{MOTS CLÉS}

Crustacé, Erymidae, France, homard, Jurassique, Mésozoïque, Normandie.

\section{ABSTRACT}

Among the Erymidae Van Straelen, 1925, known as early as the Late Permian (Changhsingian) and widespread in the Jurassic, the genus Enoploclytia M'Coy, 1849 seems to have a late appearance because of its lack before the Cretaceous. Until now, the oldest representative was E. augustobonae Devillez, Charbonnier, Hyžný \& Leroy, 2016 from the Early Cretaceous (Barremian) of the eastern Paris basin (France). However, a new fossil collected in Normandy (France), showing the typical carapace groove pattern of Enoploclytia, attests the presence of the genus in the Late Jurassic (Oxfordian).

\section{KEY WORDS}

Crustacea, Erymidae, France, lobster, Jurassic, Mesozoic, Normandy. 


\section{INTRODUCTION}

The oldest known representative of the erymid lobsters (Decapoda, Erymidae Van Straelen, 1925) was found in the Late Permian (Changhsingian: Birshtein 1958; Glaessner 1969; Feldmann et al. 2015; Devillez \& Charbonnier 2017) and fossils of erymids are common around the world during the Jurassic, mainly the representatives of Eryma Meyer, 1840 (Oppel 1862; Van Straelen 1925; Förster 1966; Charbonnier et al. 2012b).

Another genus, Enoploclytia, was erected by M'Coy (1849) who observed the "peculiar branchial furrows and ridges" and the ornamentation of carapace and chelae on fossils from the Cretaceous chalk of the United Kingdom previously assigned to Astacus Fabricius, 1775 (Mantell 1822, 1824, 1833, 1844). Furthermore, fossils from the Cretaceous Bohemian Basin of the Czech Republic described as Astacus (Geinitz 1839) or as Klytia Meyer, 1840 (Reuss 1845) also fit the description of M'Coy's genus. Later, additional representatives of Enoploclytia were reported around the world: in Europe (Reuss 1854; Quenstedt 1852; Schlüter 1862, 1879; Fritsch \& Kafka 1887; Wanderer 1908; Woods 1930; Glaessner 1932; Van Straelen 1936; Mertin 1941; Förster 1966; Morris 1987; Jagt \& Fraaije 2002; Garassino et al. 2009; Devillez et al. 2016), in North America (Woodward 1900; Rathbun 1935; Stenzel 1945; Feldmann \& McPherson 1980; Vega et al. 2007, 2013), in South America (Aguirre-Urreta 1982), in Africa (Joleaud \& Hsu 1935), in Madagascar (Secrétan 1964; Charbonnier et al. 2012a), and in Antarctica (Taylor 1979; Feldmann 1984). All the occurrences were reported from the Cretaceous. The oldest species occurs in Early Cretaceous (Barremian: Devillez et al. 2016), but Enoploclytia became the most diversified erymid genera in Late Cretaceous (Devillez et al. 2017) and persisted beyond the Cretaceous-Paleogene boundary (Vega et al. 2007; Devillez \& Charbonnier 2017). Because Enoploclytia occurs only from the second half of Early Cretaceous, the genus was therefore supposed to have appeared late in the erymid evolutionary history.

The purpose of this paper is to describe a fossil collected in the Late Jurassic deposits of western France. The specimen shows morphological features characteristic of Enoploclytia and suggest an earlier appearance of this genus.

\section{GEOLOGICAL SETTING}

The studied specimen comes from the Jurassic deposits at Cricqueboeuf, Normandy, France (Fig. 1A). The Jurassic is here represented by upper Oxfordian and lower Kimmeridgian deposits (Guyader 1968, Guyader et al. 1968; Fig. 1B). In this area, the original monoclinal structure of the deposits is included within the landslide of the "Fosses du Macre" (Lissak 2012). So, the deposits described below are not really in situ and they were observed at the bottom of the slope, on the foreshore when it was not buried in sand. 
The Oxfordian is represented by the clays and the ferruginous sandstones of Villerville which encompass the Ringsteadia pseudocordata ammonite biozone. The most basal part corresponds to the Black Clays of Villerville. We distinguish the inferior part made of fossiliferous black clays overlained by a marly limestone deposit and by greenish sands. The sands are under fossiliferous silty black clays, including tree trunks covered by oysters. Above some pebble beds, the second half of Oxfordian deposits are dominated by an alternance of brown clays, beds of sandstones (sometime oolitic and ferruginous), and a fossiliferous puddingstone.

The basis of the Kimmeridgian deposits corresponds to the Pictonia baylei ammonite biozone. The most basal part is marked by a bed of limestone with ferruginous debris and includes ammonites, nautiluses and numerous gastropods and bivalves. This limestone is immediately overlained by a deposit of brown clays intercalated with a bed of oysters (Liostrea Douvillé, 1904) surrounded by pebble beds. The top of the Kimmeridgian deposits is made of limestones which correspond to the Rasenia cymodoce ammonite biozone. The top of these limestones is eroded by a postJurassic emersion surface and yields fossil gastropods (Harpagodes Gill, 1870).

The studied fossil crustacean comes from the slided Oxfordian deposits (R. pseudocordata zone) on the foreshore. Because of the shift of the deposits, the outcrop shows them with some disturbances. Moreover, the outcrop is partially covered by sand and the series was not entirely observed. Although the characteristics of the outcrop prevent to know precisely the stratigraphic position of the fossil, it is included within a nodule similar to those of the fossiliferous and ferruginous puddingstone and of the oolitic ferruginous sandstone (Fig. 1B).

\section{MATERIAL AND METHODS}

The specimen presented here was studied using a binocular microscope. It is included in a black silicified carbonate nodule. This dark color makes difficult the observation of anatomic features on photographies. Then, to reveal the characters we whitened the specimen with ammonium chloride.

This fossil is stored in the palaeontological collections of the Muséum national d'Histoire naturelle of Paris (MNHN.F.A66892).

\section{SYSTEMATIC PALAEONTOLOGY}

MALACOSTRACA Latreille, 1802

DECAPODA Latreille, 1802

ERYMIDA sensu Schram \& Dixon, 2004

Superfamily ERYMOIDEA Van Straelen, 1925

Family ERYMIDAE Van Straelen, 1925 
PRELIMINARY REMARK. - The phylogenetic position of Erymidae is debated in the literature. This family was included within Astacidea Latreille, 1802 by many authors (Van Straelen 1925; Glaessner 1969; Aguirre-Urreta 1989; Schweigert et al. 2000; Garassino \& Krobicki 2002; Crônier \& Courville 2004; Garassino \& Schweigert 2006; Feldmann \& Titus 2006; Schweigert 2013; Charbonnier et al. 2013) or within Glypheidea Zittel, 1885 (De Grave et al. 2009; Schweitzer et al. 2010; Wahle et al. 2012; Karasawa et al. 2013; Feldmann et al. 2015). However, the latest phylogenetic analysis of Charbonnier et al. (2015) focusing on Glypheidea reject this assignment. In conclusion, we consider the phylogenetic position of Erymidae to be uncertain and, following Hyžný et al. (2015) and according to Schram \& Dixon (2004), we do not list taxonomic rank beyond superfamily. Then we therefore include Erymidae within a separate clade: Erymida.

Genus Enoploclytia M'Coy, 1849

(Fig. 2A-B)

Enoploclytia M'Coy, 1849: 330.

Enoploclytia - M'Coy 1854: 137. — Zittel 1885: 694. — Fritsch \& Kafka 1887: 27. — Van Straelen 1925: 278. — Beurlen 1928: 164. — Rathbun 1926: 128. — Secrétan 1964: 81. — Förster 1966: 146. — Taylor 1979: 25. — Aguirre-Urreta 1989: 514. — Feldmann et al. 2015: 3. — Devillez et al. 2016: 530. — Devillez et al. 2017: 786.

Enoploclytia (Enoploclytia) — Mertin 1941: 160. — Glaessner 1969: 455.

TYPE SPECIES. - Astacus leachii Mantell, 1822, by original designation.

INCLUDED SPECIES. - Jurassic: Enoploclytia sp. (present work). - Cretaceous: E. augustobonae Devillez et al., 2016 (Barremian; France); E. collignoni Secrétan, 1964 (Campanian; Madagascar); E. gigantea Devillez et al., 2016 (Albian; USA); E. leachi (Mantell, 1822) (Cenomanian - Campanian; Belgium, Czech Republic, France, Germany, United Kingdom); E. minor Woodward, 1900 (Maastrichtian; Canada); E. seitzi Glaessner, 1932 (Albian - Cenomanian; Germany, United Kingdom); E. tepeyacensis Vega et al., 2013 (Campanian; Mexico); E. tumimana Rathbun, 1935 (Maastrichtian; USA); E. wintoni Stenzel, 1945 (Albian; USA) (after Devillez et al. 2016; Devillez et al. 2017). - Paleogene: E. gardnerae (Rathbun, 1935) (Thanetian Ypresian; USA and Mexico).

DIAGNOSIS. - Fusiform intercalated plate; wide, deep cervical groove, joined to dorsal margin and to antennal groove; long, wide gastro-orbital groove originating as median inflexion of cervical groove, delimiting two gastro-orbital lobes; sinuous postcervical groove, joined to dorsal margin and to hepatic groove, with ventral extension at carapace mid-height; short branchio-cardiac groove, interrupted in upper part of carapace, joined to dorsal margin, not joined to postcervical groove; concavo-convex hepatic groove, joined to cervical groove; prominent $\omega$ and $\chi$ bulges; inferior groove 
convex posteriorly, joined to hepatic groove; carapace with heterogeneous coarse ornamentation; massive globose $\mathrm{P} 1$ propodus, rounded in transversal section; long and thin P1 fingers (straight in dorsal view); occlusal margins armed with sharp and slender tooth; P1 merus with strong, prominent distal process at extern side of its ventral extremity (after Devillez et al. 2017).

\section{Enoploclytia sp.}

(Fig. 2C-E)

MATERIAL. - Specimen MNHN.F.A66892 (Pezy coll.) from the Oxfordian of Cricqueboeuf, France.

DESCRIPTION. - Subcylindrical carapace; rostrum and intercalated plate not preserved; wide cervical groove, slightly inclined, joined to antennal groove; deep antennal groove; long gastro-orbital groove, with two divergent branches delimiting two gastro-orbital lobes (inflated lower lobe, flat upper lobe); slightly sinuous postcervical groove, with a ventral extension at carapace mid-height, joined to posterior extremity of hepatic groove; narrow branchiocardiac groove, interrupted in branchial region; concavoconvex hepatic groove, joined to cervical groove; inflated attachment site of mandibular muscle; inflated and elongated attachment site of adductor testis muscle; inferior groove partially preserved, joined to posterior extremity of hepatic groove; strong antennal spine; oblique row of tubercles in antennal region; elongated merus of first chelipeds, subtriangular in section; wide carpus of first chelipeds.

DISCUSSION. - The specimen discussed herein preserves the merus and carpus of the left first pereiopod connected to the carapace and a pleonal somite. The carapace groove pattern is relatively well-preserved with: the inferior half of the cervical groove, the posterior part of the antennal groove, the elongated and bifurcated gastro-orbital groove, the postcervical groove, the branchiocardiac groove, the hepatic groove and the dorsal part of the inferior groove. The shape of the carapace and this combination of grooves is typical of the Erymidae. Among this family, the absence of connection between the branchiocardiac and the hepatic groove (present in Eryma Meyer, 1840, Palaeastacus Bell, 1850 and Stenodactylina Beurlen, 1928), the sinuous hepatic groove (concave in Pustulina Quenstedt, 1857 and Tethysastacus Devillez et al., 2016), the shape of the post-cervical groove and its connection to the posterior extremity of hepatic groove are typical of Enoploclytia. The poor preservation of the specimen does not allow the observation of the ornamentation, which is an important character used in specific identification of erymid lobsters. This prevents therefore identification at the species level. Furthermore, comparison with other species are limited to some details of the groove pattern, the presence of some inflated areas and the presence of a row of tubercles in antennal region. The dorsal part of the postcervical groove is less inflected than E. tepeyacensis and the development of the inferior branch of the gastro-orbital groove is similar to those of E. augustobonae and E. gigantea from the Early Cretaceous. The specimen also shares well-marked antennal row and inflated 
attachment sites of mandibular muscle and of adductor testis muscle with E. collignoni and E. leachi from the Late Cretaceous.

BIOSTRATIGRAPHIC IMPLICATIONS. - Enoploclytia is considered to be typical of the Cretaceous because of its supposed absence in Jurassic deposits and the numerous fossils found in Europe, particularly in Cenomanian - Turonian deposits (Devillez et al. 2017). The fossil described here is the first report of Enoploclytia in the Jurassic and demonstrates that the supposed absence of the genus before the Cretaceous was related to collect bias. This new occurrence in the Jurassic supports an earlier appearance of the genus in erymids evolutionary history.

The gap of almost 25 million years between this occurrence (Oxfordian) and the next occurrence, E. augustobonae (Barremian), the gap of almost 50 million years between the two oldest species of Eryma, E. antiquum (Birshtein, 1958) (Changhsingian), and E. sinemuriana (Garassino, 1996) (Sinemurian; Devillez \& Charbonnier 2017), and the gap of almost 50 million years between the two oldest Cretaceous occurences of Stenodactylina, S. delphinensis (Berriasian) and S. triglypta (Coniacian; Devillez et al. 2017), are all examples that clearly demonstrate the strong dicontinuities and fragmentation in the fossil record of erymid lobsters.

\section{CONCLUSION}

Despite a poor preservation, most of the carapace grooves of the fossil presented here are preserved. Carefull examination of the specimen has allowed us to identify the typical groove pattern of Enoploclytia, but the almost complete lack of preservation of the ornamentation prevents identification at the species level. So, we identify this specimen as Enoploclytia sp.

This fossil, found in Oxfordian deposits of Normandy (Western France), is the first occurrence of the genus in the Jurassic and demonstrates that the supposed absence of Enoploclytia before the Cretaceous was due to collecting bias. Furthermore, the lack of occurences of Enoploclytia between its two oldest occurences is another example of the strong discontinuities in the fossil record of erymid lobsters.

In conclusion, we noticed that the locations of the oldest occurences of Enoploclytia (Oxfordian of France, present work; Barremian of France; Devillez et al. 2016; Aptian of Spain, Garassino et al. 2009) might indicate an European origin of this genus, even if its fossil record is probably too scarce to be completely affirmative.

\section{ACKNOWLEDGEMENTS}

The authors are gratefull to Lilian Cazes and Philippe Loubry (MNHN, Paris, France) for the whitening and the photographs of the specimen. We also wish to acknowledge Denis Audo and Gérard Breton for their useful advices and comments which greatly improved our original manuscript. 


\section{REFERENCES}

Aguirre-Urreta M. B. 1982. Crustaceos Decapodos Barremianos de la region del TucuTucu, Provincia de Santa Cruz. Revista de la Asociación Paleontológica Argentina 19 (3-4), 303-317.

Aguirre-Urreta M. B. 1989. The Cretaceous decapod Crustacea of Argentina and the Antarctic Peninsula. Palaeontology 32 (3), 499-552.

Bell T. 1850. Notes on the Crustacea of the Chalk Formation, in Dixon F. (ed.), The Geology and Fossils of the Tertiary and Cretaceous Formations of Sussex. Longman, Brown, Green and Longmans, London, 344-345.

Beurlen K. 1928. Die Decapoden des Schwäbischen Jura mit Ausnahme der aus den oberjurassischen Plattenkalken stammenden. Palaeontographica 70, 115-278.

Birshtein J. A. 1958. Ein Vertreter der ältesten Ordo der Crustacea Decapoda Protoclitiopsis antiqua gen. nov. sp. nov. aus dem Permo West-Sibiriens. - Doklady Akademii Nauk, SSSR, 122, 477-480.

Charbonnier S., Audo D., Barriel V., Garassino A., Schweigert G. \& Simpson M. 2015. Phylogeny of fossil and extant glypheid and litogastrid lobsters (Crustacea, Decapoda) as revealed by morphological characters. Cladistics 31, 231-249.

Charbonnier S., Garassino A. \& Pasini, G. 2012a. Revision of Mesozoic decapod crustaceans from Madagascar. Geodiversitas 34 (2), 313-357.

Charbonnier S., Pérès D. \& Letenneur C. 2012b. Exceptionally preserved crustaceans from the Oxfordian of eastern France (Terrain à Chailles Formation, Haute-Saône). Geodiversitas 34 (3), 531-568.

Charbonnier S., Garassino A., Schweigert G. \& Simpson M. 2013. A worldwide review of fossil and extant glypheid and litogastrid lobsters (Crustacea, Decapoda, Glypheoidea). Mémoires du Muséum national d'Histoire naturelle 205, 304 p.

Crônier C. \& Courville P. 2004. A rich and highly endemic decapod crustacean fauna from the Middle Jurassic of north-east France. Palaeontology 47 (4), 999-1014.

De Grave S., Pontcheff N. D., Ahyong S. T., Chan T.-Y., Crandall K. A., Dworschak P. C., Felder D. L., Feldmann R. M., Fransen C. H. M., Goulding L. Y. D., Lemaitre R., Low M. E. Y., Martin J. W., Ng P. K. L., Schweitzer C. E., Tan S. H., Thsudy D. \& Wetzer R. 2009. A classification of living and fossil genera of decapod crustaceans. The Raffles Bulletin of Zoology, supplement 21, 1-109.

Devillez J. \& Charbonnier S. 2017. The genus Eryma Meyer, 1840 (Crustacea: Decapoda: Erymidae): new synonyms, systematic and stratigraphic implications. Bulletin de la Société géologique de France 188 (3), 1-10.

Devillez J., Charbonnier S., Kocová Veselská M. \& Pezy J.-P. 2017. Review of the Late Cretaceous erymid lobsters (Crustacea: Decapoda) from the Western Tethys. Proceedings of the Geologists' Association, 779-797.

Devillez J., Charbonnier S., Hyžný M. \& Leroy L. 2016. Review of the Early Cretaceous erymid lobsters (Crustacea: Decapoda) from the Western Tethys. Geodiversitas 38 (4), 515-541.

Douvillé J.H.F. 1904. Paléontologie, mollusques fossiles, in Morgan J.D. (ed.), Mission Scientifique en Perse 3. Études géologiques. Partie 4. E. Leroux, Paris, 191-380. 
Fabricius J. C. 1775. Systema entomologiae : sistens insectorum classes, ordines, genera, species, adiectis synonymis, locis, descriptionibus, observationibus. Flansburgi and Lipsiae, $832 \mathrm{p}$.

Feldmann R. M. 1984. Decapod crustaceans from the Late Cretaceous and the Eocene of Seymour Island, Antarctic Peninsula. Antarctic Journal, 4-5.

Feldmann R. M. \& McPherson C. B. 1980. Fossil decapod crustaceans of Canada. Geological Survey of Canada Paper 79-16, 1-20.

Feldmann R. M., Schweitzer C. E. \& Karasawa H. 2015. Crustacea, in Selden P. A. (ed.), Treatise online, Part R (Revised), Arthropoda 4 (1), Chapter 8I, 1-28.

Feldmann R. M. \& Titus A. L. 2006. Eryma jungostrix n.sp. (Decapoda; Erymidae) from the Redwater Shale of the Stump Formation (Jurassic; Oxfordian) of Utah. Journal of Crustacean Biology 26 (1), 63-68.

Förster R. 1966. Über die Erymiden, eine alte konservative Familie der mesozoischen Dekapoden. Palaeontographica A125 (4-6), 61-175.

Fritsch A. \& Kafka J. 1887. Die Crustaceen der Böhmischen Kreideformation. Prague, $53 \mathrm{p}$.

Garassino A. 1996. The family Erymidae Van Straelen, 1924 and the superfamily Glypheoidea Zittel, 1885 in the Sinemurian of Osteno in Lombardy (Crustacea, Decapoda). Atti della Società italiana di Scienze naturali e del Museo civico di Storia naturale in Milano 135, 333-373.

Garassino A., Artal P. \& Pasini G. 2009. New records of decapod macrurans from the Cretaceous of Catalonia and the Province of Castellón (Spain). Bulletin of the Mizunami Fossil Museum 35, 87-95.

Garassino A. \& Krobicki M. 2002. Galicia marianae n. gen., n. sp. (Crustacea, Decapoda, Astacidea) from the Oxfordian (Upper Jurassic) of the Southern Polish Uplands. Bulletin of the Mizunami Fossil Museum 29, 51-59.

Garassino A. \& Schweigert G. 2006. The Upper Jurassic Solnhofen decapod crustacean fauna: review of the types from old descriptions. Part I. Infraorders Astacidea, Thalassinidea and Palinura. Memorie della Società italiana di Scienze naturali e del Museo civico di Storia naturale di Milano 34 (1), 1-64.

Geinitz H. B. 1839-1842. Charakteristik der Schichten und Petrefacten des sächsischböhmischen Kreidegebirges. Dresde und Leipzig, 116 p.

Gill T. 1870. On the Pterocerae of Lamarck, and their mutual relations. American journal of Conchology 5 (3), 120-139.

Glaessner M. F. 1932. Neue Krebsreste aus der Kreide. Jahrbuch der Preussischen Geologischen Landesanstalt 53, 577-586.

Glaessner M. F. 1969. Decapoda, in Moore R. C. (ed.), Treatise on Invertebrate Paleontology, Part R, Arthropoda 4 (2), 399-533.

Guyader J. 1968. Le Jurassique supérieur de la baie de la Seine - Étude stratigraphique et micropaléontologique. Thesis presented at the Faculté des Sciences de Paris, November $19^{\text {th }} 1968,269$ p.

Guyader J., Pareyn C. \& Viallefond L. 1968. Carte géologique de la France à 1/50 000 : Le Havre (feuille 97). 2e édition. BRGM, Orléan. 
Hyžný M., Schlögl J., Charbonnier S., Schweigert G., Rulleau L. \& Gouttenoire M. 2015. Intraspecific variation and taphonomy of a new erymid lobster (Crustacea: Decapoda) from the Middle Jurassic of Belmont (Beaujolais, France). Geobios 48, 371-384.

Jagt W. M. \& Fraaije R. H. B. 2002. The erymid lobster Enoploclytia leachii (Mantell, 1822) from the Upper Campanian of northeast Belgium. Bulletin de l'Institut royal des sciences naturelles de Belgique, Sciences de la Terre 72, 91-95.

Joleaud L. \& Hsu T.-Y. 1935. Crustacés décapodes du Crétacé de Tanout (Damergou, Niger français). Archives du Muséum national d'Histoire naturelle 13 (6), 99-110.

Karasawa H., Schweitzer C. E. \& Feldmann R. M. 2013. Phylogeny and Systematics of extant and extinct lobsters. Journal of Crustacean Biology 33 (1), 78-123.

Latreille P. A. 1802. Histoire Naturelle, Générale et Particulière des Crustacés et des Insectes. Tome 3. F. Dufart, Paris, 468 p.

Lissak C. 2012. Les glissements de terrain des versants côtiers du Pays d'Auge (Calvados) : Morphologie, fonctionnement et gestion du risque. Thesis presented at the Université de Caen Basse-Normandie, December $12^{\text {th }} 2012,312$ p.

Mantell G. A. 1822. The Fossil of the South Downs; or Illustrations of the Geology of Sussex. Lupton Relfe, London, 327 p.

Mantell G. A. 1824. Outlines of the natural history, of the environs of Lewes, in Horsfield T. W. (ed.), The History and antiquities of Lewes and its vicinity. J. Baxter, Lewes, 344 p.

Mantell G. A. 1833. The Geology of the South-East of England. Longman, Rees, Orme, Brow, Green \& Longman, London, 415p.

Mantell G. A. 1844. The Medals of Creation; or, First Lessons in Geology and in the Study of Organic Remains, Volume II. Henry G. Bohn, London, 459-1016.

M'Coy F., 1849. On the classification of some British Fossil Crustacea, with Notices of new Forms in the University Collection at Cambridge. Annals and Magazine of Natural History, including Zoology, Botany, and Geology 4 (2), 330-335.

M'Coy F., 1854. Contributions to British Palaeontology, or first descriptions of three hundred and sixty species and several genera of fossil Radiata, Articulata, Mollusca, and Pisces from the Tertiary, Cretaceous, Oolitic, and Palaeozoic strata of Great Britain. Macmillan and co., Cambridge, 272 p.

Mertin H. 1941. Decapode Krebse aus dem subhercynen und Braunschweiger Emscher und Untersenon. Nova Acta Leopoldina 68 (10), 149-264.

Meyer H. von 1840. Neue Gattungen fossiler Krebse aus Gebilden vom bunten Sandstein bis in die Kreide. E. Schweizerbart'sche Verlagshandlung, Stuttgart, 28 p.

Morris S. F. 1987. Arthropods, in Smith A. B. (ed.), Fossils of the Chalk. The Palaeontological Association, London, $306 \mathrm{p}$.

Oppel A. 1862. Ueber jurassische Crustaceen (Decapoda macrura). Palaeontologische Mittheilungen aus dem Museum des koeniglich Bayerischen Staates 1, 1-120.

Quenstedt F. A. 1852. Handbuch der Petrefaktenkunde. H. Laupp, Tübingen, 792 p.

Quenstedt F. A. 1857. Der Jura. H. Laupp, Tübingen, 842 p. 
Rathbun M. J. 1926. The fossil stalk-eyed crustacea of the Pacific Slope of North America. United States National Museum Bulletin 138, 1-155.

Rathbun M. J. 1935. Fossil Crustacea of the Atlantic and Gulf Coastal Plain. Geological Society of America Special Papers 2, 1-160.

Reuss A. E. 1845. Die Versteinerungen der böhmischen Kreideformation. Schweizerbart, Stuttgart, 148 p.

Reuss A. E. 1854. Über Klytia Leachi, einen langschwänzigen Decapoden der Kreideformation. Denkschriften der kaiserlichen Akademie der Wissenschaften 6, $1-10$.

Schlüther C. 1862. Die Macruren Decapoden der Senon- und Cenoman-Bildungen Westphalens. Zeitschrift der Deutschen geologischen Gesellschaft 14, 702-749.

Schlüter C. 1879. Neue und weniger bekannte Kreide- und Tertiär-Krebse des nördlichen Deutschlands. Zeitschrift der Deutschen geologischen Gesellschaft 31, 586-615.

Schram F. R. \& Dixon C. J. 2004. Decapod phylogeny: addition of fossil evidence to a robust morphological cladistics data set. Bulletin of the Mizunami Fossil Museum 31, 1-19.

Schweigert G. 2013. A new record of the enigmatic lobster genus Stenodactylina Beurlen, 1928 (Crustacea: Decapoda: Erymidae) from the Middle Jurassic of southwestern Germany. Paläontologische Zeitschrift 87, 409-413.

Schweigert G., Dietl G. \& Röper M. 2000. Die Panzerkrebse des Familie Erymidae van Straelen (Crustacea, Decapoda) aus dem Nusplinger Plattenkalk (OberKimmeridgium, Schwäbische Alb) im Vergleich mit fränkischen Vorkommen. Stuttgarter Beiträge zur Naturkunde B (285), 1-25.

Schweitzer C. E., Feldmann R. M., Garassino A., Karasawa H. \& Schweigert G. 2010. Systematic list of fossil decapod crustacean species. Crustaceana Monographs 10, $1-222$.

Secrétan S. 1964. Les Crustacés décapodes du Jurassique supérieur et du Crétacé de Madagascar. Mémoires du Muséum national d'Histoire naturelle, Nouvelle série, Série C, Sciences de la Terre 14, 1-226.

Stenzel H. B. 1945. Decapod Crustacea from the Cretaceous of Texas. Texas University Publications 4401, 401-476.

Taylor B. J. 1979. Macrurous Decapoda from the Lower Cretaceous of South-Eastern Alexander Island. British Antarctic Survey Scientific Reports 81, 1-39.

Van Straelen V. 1925. Contribution à l'étude des crustacés décapodes de la période jurassique. Mémoires de la Classe des Sciences de l'Académie royale de Belgique 7, 1-462.

Van Straelen V. 1936. Crustacés décapodes nouveaux ou peu connus de l'époque crétacique. Bulletin du Musée royal d'Histoire naturelle de Belgique 12 (45), 1-50.

Vega F. J., Garassino A. \& Jaime R. Z. 2013. Enoploclytia tepeyacensis n. sp. (Crustacea, Decapoda, Erymidae) from the Cretaceous (Campanian) of Coahuila, NE Mexico. Boletín de la Sociedad Geológica Mexicana 65 (2), 207-211. 
Vega F. J., Nyborg T., Fraaije H. B. \& Espinosa B. 2007. Paleocene Decapod Crustacea from the Rancho Nuevo Formation (Parras Basin-Difunta Group), Northeastern Mexico. Journal of Paleontology 81 (6), 1432-1441.

Wahle R. A., Thsudy D., Cobb J. S., Factor J. \& Jaini M. 2012. Infraorder Astacidea Latreille, 1802 p. p.: The Marine Clawed Lobsters, in Schram F. R., Vaupel Klein J. C. von, Charmantier-Daures M. \& Forest J. (eds.) Treatise of Zoology Anatomy, Taxonomy, Biology - The Crustacea, Volume 9, Part B, Eucarida, Astacidea P. P. (Enoplometopoidea, Nephropoidea), Glypheidea, Axiidea, Gebiidea, and Anomura. Brill, Leiden \& Boston, 3-108.

Wanderer K. 1908. Ein Vorkommen von Enoploclytia leachi Mant. sp. im Cenoman von Sachsen. Abhandlungen der Naturwissenschaftlichen Gesellschaft ISIS in Dresden, 23-24.

Woods H. 1925-1931. A Monograph of the Fossil Macrurous Crustacea of England. The Palaeontographical Society, London, 1-122.

Woodward H. 1900. Further Notes on Podophthalmous Crustaceans from the Upper Cretaceous Formation of British Columbia. Geological Magazine 7, 302-401 and 433-435.

Zittel K. A. von 1885. Handbuch der Palaeontologie 1 (2) (Arthropoda, Decapoda), 523-721. 

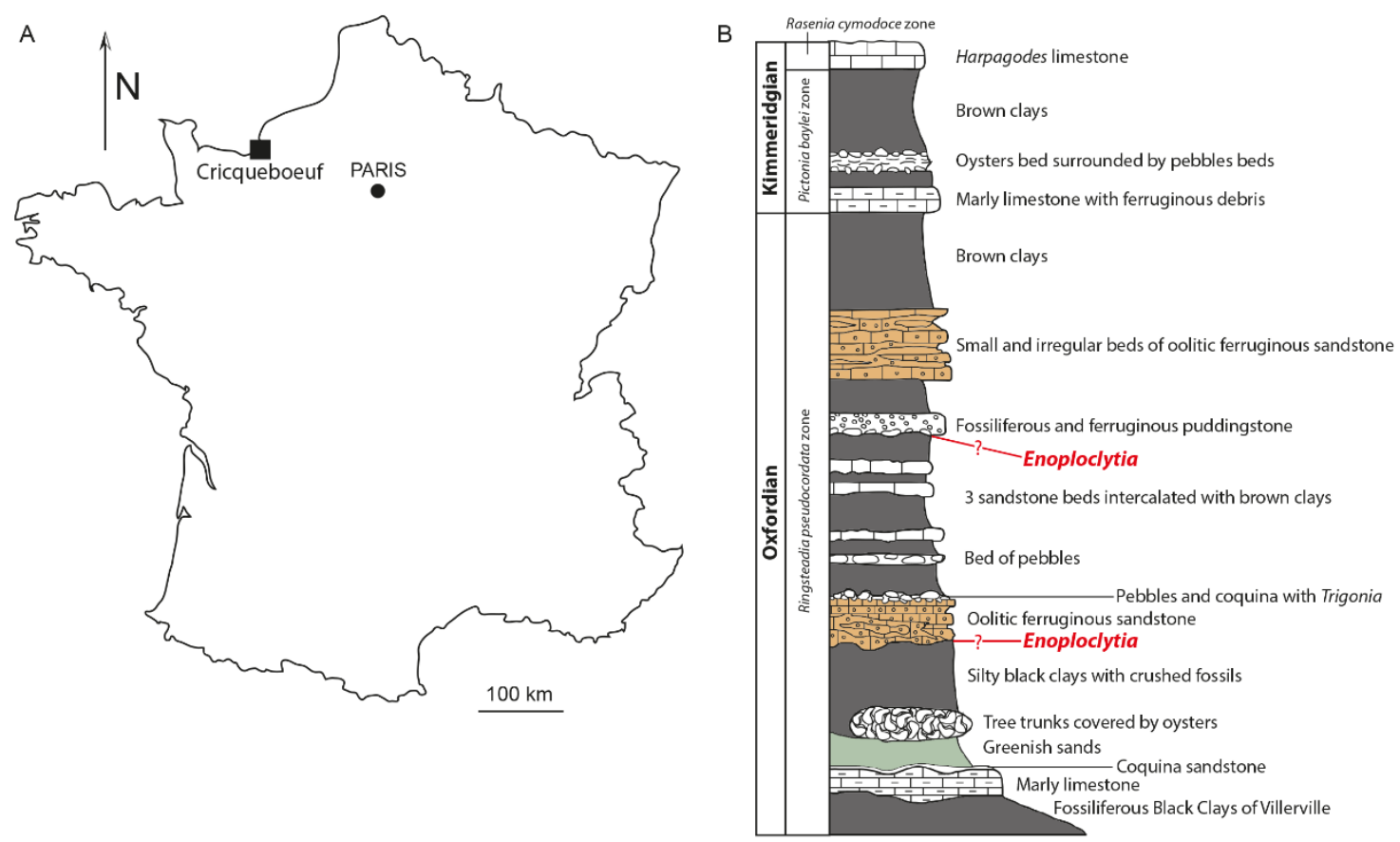

FIG. 1. - Cadre géographique et géologique. A, localisation de l'affleurement; B, colone stratigraphique de la succession Oxfordien supérieur - Kimméridgien à Cricqueboeuf (d'après Guyader 1968) avec les possibles localisations du fossile d'Enoploclytia M'Coy, 1849.

Geographic and geological settings. A, location of the outcrop; B, stratigraphic log of the Upper Oxfordian - Kimmeridgian succession of Cricqueboeuf (after Guyader 1968) with the possible stratigraphic locaions of the specimen of Enoploclytia M'Coy, 1849. 


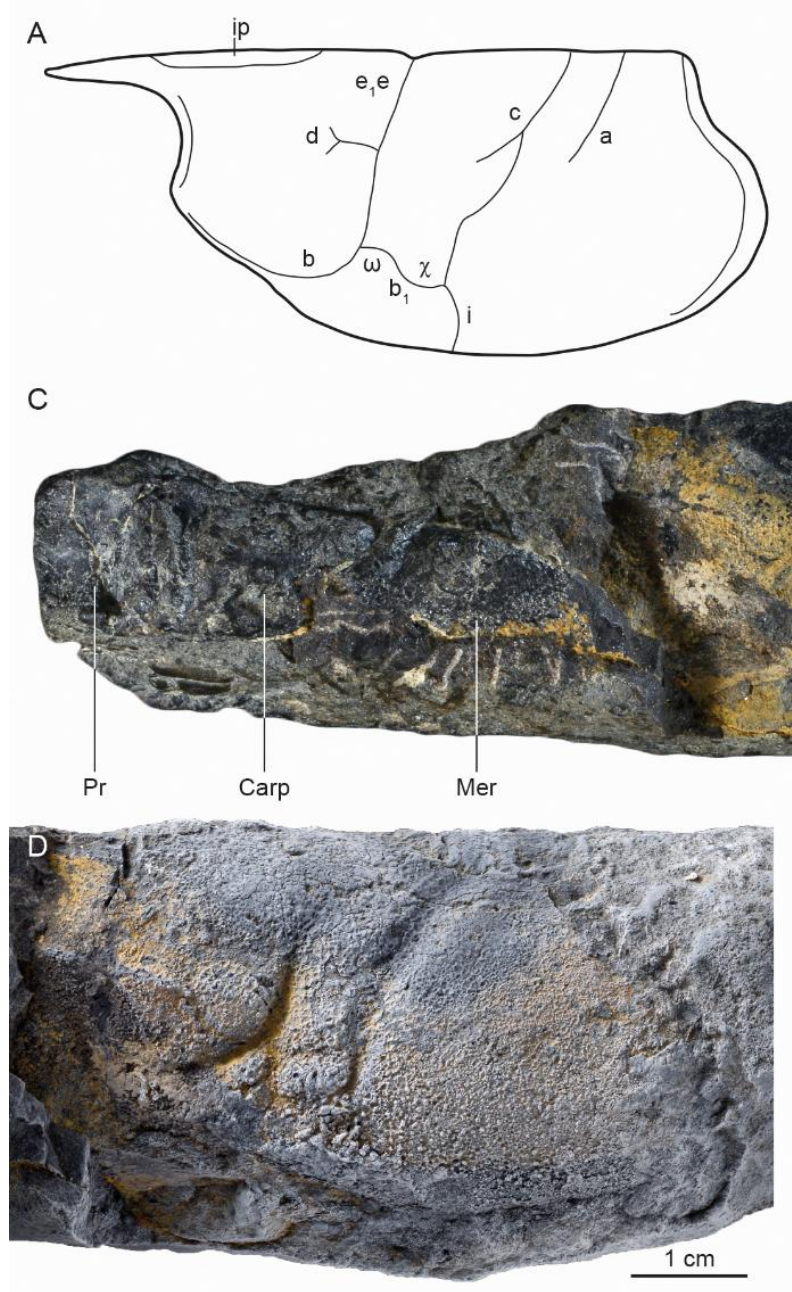

B
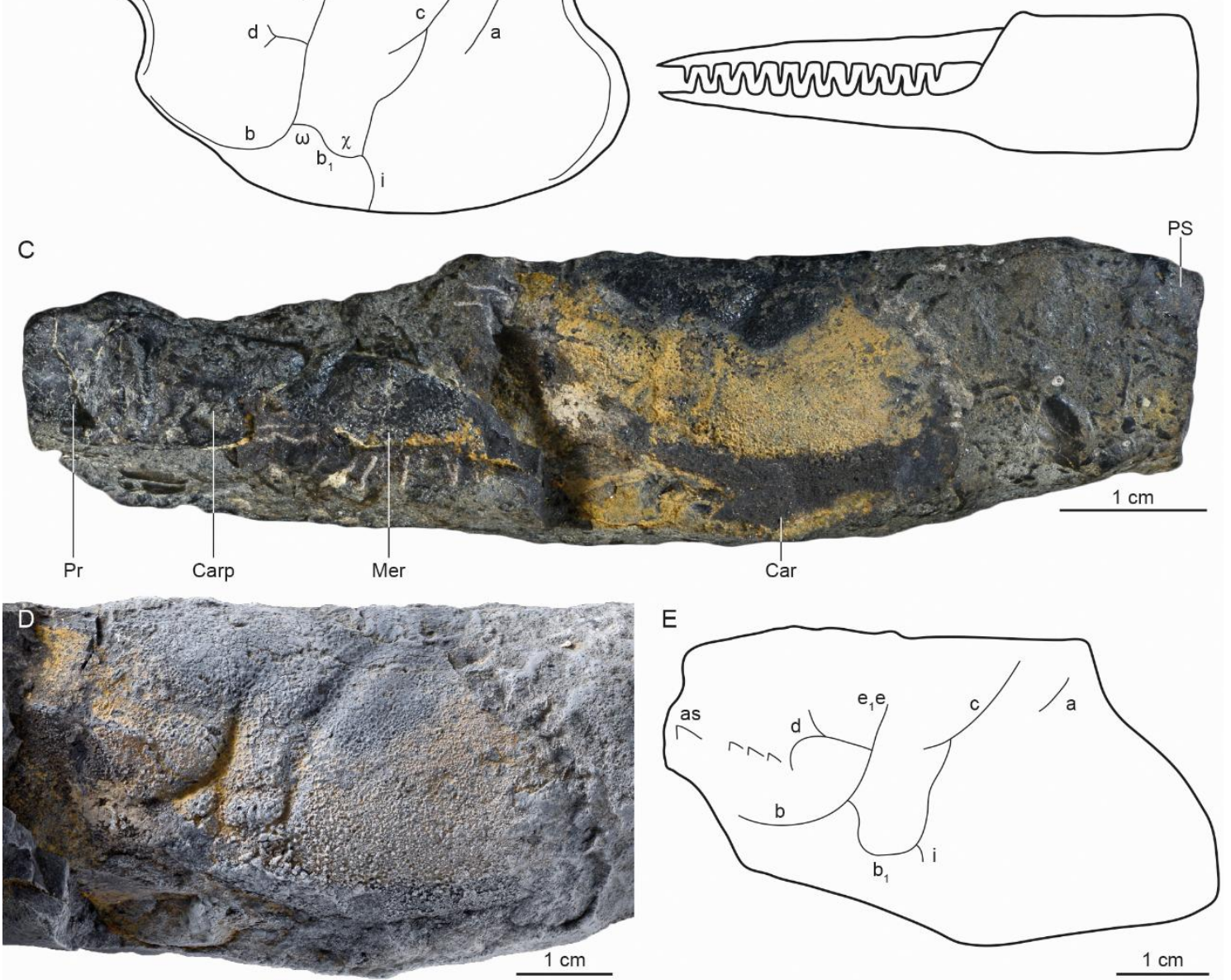

FIG. 2. - Enoploclytia M'Coy, 1849. A, architecture générique des sillons de la carapace; $\mathbf{B}$, pince caractéristique de la première paire de péréiopodes; $\mathbf{C}-\mathbf{E}$, spécimen MNHN.F.A66892 (coll. Pezy) d'Enoploclytia sp. de l'Oxfordien de Cricqueboeuf, Normandie, France: vue latérale gauche de la carapace et du premier chélipède (C), détail de la carapace blanchie au chlorure d'ammonium (D) et schéma des sillons (E). Abréviations : a : sillon branchio-cardiaque ; as : épine antennaire ; b : sillon antennaire ; $b_{1}$ : sillon hépatique ; $\mathrm{c}$ : sillon post-cervical ; Car : carapace ; Carp : carpus ; $\mathrm{d}:$ sillon gastro-orbitaire $; \mathrm{e}_{1} \mathrm{e}:$ sillon cervical ; $\mathrm{i}$ : sillon inférieur ; ip : plaque intercalaire ; Mer : mérus ; $\operatorname{Pr}$ : propode ; PS : somite du pléon ; $\omega$ : site d'attache des muscles mandibulaires $; \chi$ : site d'attache des muscles adducteurs. Photographies : P. Loubry (C) et L. Cazes (D). Dessins au trait : J. Devillez.

Enoploclytia M'Coy, 1849. A, general carapace groove pattern; B, chela characteristic of the first pair of pereiopods; C-E, specimen MNHN.F.A66892 (Pezy coll.) of Enoploclytia sp. from the Oxfordian of Cricqueboeuf, Normandy, France: left lateral view of carapace and first cheliped $(\mathrm{C})$, detail of the carapace covered by ammonium chloride (D) and line drawing of the grooves (E). Abbreviations: a: branchiocardiac groove; as: antennal spine; b: antennal groove; $b_{1}$ : hepatic groove; $c$ : postcervical groove; Car: carapace; Carp: carpus; d: gastro-orbital groove; $\mathrm{e}_{1} \mathrm{e}$ : cervical groove; $\mathrm{i}$ : 
inferior groove; ip: intercalated plate; Mer: merus; Pr: propodus; PS: pleonal somite; $\omega$ : attachment site of mandibular muscle; $\chi$ : attachment site of adductor testis muscle. Photographs: P. Loubry (C) and L. Cazes (D). Line drawings: J. Devillez. 